\title{
Relating Shared Vision Components To Thai Public School Performance
}

\author{
Sooksan Kantabutra, Mahidol University, Thailand
}

\begin{abstract}
While shared vision is core to the prevailing vision-based leadership theories, little is known about the relationship between performance and the characteristics of visions shared between leader and followers. This paper proposes a model in public schools for future research to address this gap. The model proposes relationships between shared vision and public school performance as measured by school efficiency. Hypotheses and future research directions are discussed.
\end{abstract}

Keywords: Vision; School Performance; Public Sector; Visionary Leadership; Vision Theory

\section{INTRODUCTION}

overnments in the Asia Pacific region are finding it increasingly difficult to put their educational policies into practice because of the ever-changing rate and scope of global changes (Caldwell, 1998; Cheng and Townsend, 2000; Dimmock and Walker, 1998; Fullan, 1990; Hallinger, 1998; Hargreaves and Fullan, 1998; Murphy and Adam, 1998). Educational leaders will need to look ahead to the future and scan the environment for change forces coming to schools from the outside, a CEO-like function called "visioning" (Bolman and Deal, 1992; Deal and Peterson, 1990; Leithwood, 1994). To many experts, leadership with vision as a core component is the most appropriate for public schools to bridge the gap between reforms in educational policy and implementation, given that visionary leadership was endorsed across sixty two cultures including the Thai culture (Den Hartog, House, Hanges, and Ruiz-Quintanilla, 1999).

However, a leader with a vision alone is not sufficient. Many scholars (e.g. Kantabutra, 2009a; Reardon, 1991; Sashkin, 1985; Senge, 1990) assert that vision needs to be shared between leader and followers to make an impact on organizational performance. In particular, follower affective commitment to a shared vision of education has been a hallmark of the school effectiveness and improvement literature of the past two decades (Hallinger and Heck, 2002). With the clear importance of vision sharing between leader and followers, relatively few studies have been conducted into the relationship between vision components shared between leader and followers, and organizational performance outcomes, particularly in a school setting in Thailand. Most interestingly, public school policy in Thailand is greatly influenced by the Ministry of Education, a centralized approach to management. This indicates a need to investigate whether shared vision between school principal and teachers is effective at all in this centralized setting.

In this paper, the literature on vision and school performance is reviewed. Literature from both business and education sectors forms the basis for the review. Where possible, relevant literature from Thailand is included. Then a research model is developed, showing hypothesized relationships between shared vision attributes and content, and school performance outcomes for future testing in Thai public schools. Hypotheses as well as some directions for testing them are also discussed.

\section{ESSENCE OF SHARED VISION}

A shared vision between leader and followers has been widely regarded as a key to high performance (e.g. Avery and Bergsteiner, 2010, Kantabutra, 2009a; Reardon, 1991; Sashkin, 1985; Senge, 1990). Endorsing this view, many scholars (e.g. Avery, 2004, 2005; Sashkin, 1988; Sims and Lorenzi, 1992) suggested that effective 
visions should be integrated with personal visions of others in an organization. Senge (1990) additionally emphasized the importance of a shared vision, claiming that; (a) when people truly share a vision, they are connected, bound together by a common aspiration to carry out a common goal; (b) personal visions derive their power from an individual's deep caring for the vision; and (c) one of the reasons people seek to build a shared vision is their desire to be connected in an important undertaking. A New Science view (Drath, 2001), as opposed to the Newtonian one, that effective leadership requires an alignment between leader and followers also necessitates the alignment, i.e. sharing between leader and follower visions.

In the educational setting, Hallinger and Heck (2002) pointed out that an organizational mission or shared vision exists when personal visions of a critical mass of people cohere in a common sense of purpose within a community. It is the moral character of a mission that reaches into the hearts of people and engages them to act on behalf of something beyond their own immediate self-interest. The power of a mission or shared vision lies in the motivational force of engaging in a shared quest to accomplish something special, not just reach a productivity target (Hallinger and Heck, 2002).

Shared vision is also one component of a learning organization (Senge, 1990), a concept of which invokes a lot of attention from educators. There is little doubt today that a consensus among key constituencies over values, purposes, and goals represents a desirable characteristic of schools (Hallinger, 1998). Furthermore, empirical evidence bears out that the consensus is a factor that school-level leaders can influence (Hallinger and Heck, 1997). However, there is minimal guidance on how school leaders can foster a shared vision or goal consensus (Hallinger, 1998). In Southeast Asia, schools leaders hardly asked this question, simply assuming that goal-setting was the province of the Ministry of Education and that schools would accept those purposes as meaningful and appropriate (Hallinger, 1998). This assumption does not encourage a learning organization in which staff identify needs and develop a common vision to guide future directions (Senge, 1990).

Given the definitional confusion over vision, shared visions have been studied in terms of organizational mission in much of the educational leadership research. Consistently, research on successful business organizations indicates the importance of a clear organizational mission. Among the pioneers, Peters and Waterman (1982) found that all of the successful companies in their In Search of Excellence study had a well-defined set of guiding beliefs. In these companies, the mission is broadly defined, allowing room for innovation within a general framework. Other research (e.g. Avery and Bergsteiner, 2010; Bass, 1985; Bennis and Nanus, 1985; Deal and Kennedy, 1982; Kotter, 1996) also supports this finding. Overall, it can be concluded that successful organizations have a coherent set of values that are known to members of the organization and its environment (Hallinger and Heck, 2002).

Shared vision or mission has been studied as a set of shared beliefs. A prior study (Kantabutra and Avery, 2005), however, has investigated relationships between the similarity of vision attributes and content in personal visions of leader and followers, and organizational performance in Australian apparel retailers. The study found that shared visions directly created a positive impact on overall organizational performance through customer and staff satisfaction, taking into account manager efforts at empowerment and motivation, and staff use of vision to guide daily operations. Indeed, shared vision is inherent in staff performance, therefore creating an impact on customer satisfaction.

Internationally, a number of studies have examined the role of shared vision in improving school performance (Hopkins and Ainscow, 1993; Stoll and Fink, 1992, 1994; Teddlie and Reynolds, 2000). However, there are no reported studies investigating shared vision and school performance in Thailand, although espousing a vision is widely regarded as critical to school performance here (e.g. Intasan, 2002; Sekkhunthod, 2002; Siriwat, 2002; Theppudthangkul, 2001). In an educational setting, the relationship between shared vision attributes and content, and school performance has also been largely overlooked (Kantabutra, 2010). This overlooked area is critical, for (a) vision attributes and content were found to make an impact on organizational performance (Baum, Locke, and Kirkpatrick, 1998; Kantabutra and Avery, 2010); and (b) shared vision attributes and content were also found to directly impact organizational performance via customer and staff satisfaction in positive ways (Kantabutra and Avery, 2005). Moreover, Rafferty and Griffin (2004), drawing upon their study of a large Australian public sector organization, suggest that visions do not always create a positive impact on follower attitudes, and that one should distinguish between "strong" and "weak" visions as well as vision content to see their effectiveness. 
Therefore, there is a need to identify vision components that should be shared between school leaders and followers to enhance school performance. For this reason, a research model is proposed, expressing hypothesized relationships between the shared vision components and school performance outcomes, as measured by different efficiency models, for testing in a Thai public school setting. Details are discussed next.

\section{DEFINING A VISION}

Numerous scholars agree that organizational vision is critical to effective leadership, strategy implementation and change (e.g. Avery, 2005; Collins and Porras, 1994; Doz and Prahalad, 1987; Hunt, 1991; Kotter, 1990). However, there is no generally agreed-upon definition for vision (Kantabutra, 2010a). Definitions differ from vision being a form of leadership in which a leader alters an organizational culture to bring about changes (Hunt, 1991; Sashkin, 1988), an essential task that top organizational leaders perform (Pearson, 1989; Phillips and Hunt, 1992), and an organization's image of the future (Collins and Lazier, 1992; Jacobs and Jaques, 1990), to vision being the force that moulds meaning for people in an organization (Manasse, 1986).

Complicating the situation further, much confusion exists over whether terms like mission, goals, strategy, and organizational philosophy differ from vision. Researchers often used vision, mission, and goals synonymously in discussions of educational leadership (Hallinger and Heck, 1996). They also tended to operationalize them quite differently in empirical investigation. In practice, the concepts are also mixed up, as a study that requested copies of mission statements from a number of organizations showed (Baetz and Bart, 1996). The researchers received documents with a variety of titles, including mission, vision, values, beliefs, principles, and strategic intent/ direction. This lack of conceptual clarity is problematic because these terms have different theoretical foundations and point towards alternate conceptualizations of how leaders influence school outcomes (Hallinger and Heck, 1996).

Despite its apparent importance, organizational vision is still not defined in an agreed upon manner. It is frequently confused with, or even deliberately combined with, mission, goals, strategy, values and organizational philosophy (Kantabutra, 2010a). Therefore, an organizational vision is operationally defined in the present proposal as a mental model that each leader defines, given that it is the leader's actual mental model that guides his/her choices and actions (Kantabutra, 2009a) for the following reasons. Leaders develop a vision in their own way, whether derived rationally or intuitively and subjectively (Nanus, 1992), making visionary leadership vary importantly from leader to leader in both the leader's style, the content of the leader's vision, and the context in which it takes root (Westley and Mintzberg, 1989). As a result, it is difficult to prescribe a single definition. Depending on their mental models, leaders use various techniques to induce followers to act, ranging from legitimate authority, modeling, goal-setting, rewarding and punishing, organizational restructuring, team-building, to communicating a vision (Locke et al., 1991). Adopting what individual leaders regard as a mental model thus offers a pragmatic way around many of the problems in defining vision. This approach unavoidably generates a lack of consistency in the construct, but this is not regarded as a problem in the present model which aims at exploring the hypothesized relationships between shared vision and school performance outcomes. Whatever is shared as a vision is of interest here.

\section{DEFINING A SHARED VISION}

The literature identifies two essential components of a vision: vision attributes and content. In a shared vision, attributes and content should be common, because both reflect a shared direction.

In terms of vision attributes, management writers disagree about the qualities necessary for a vision to affect performance outcomes. Views include that an effective vision is inspiring, abstract, brief, stable, and motivating (Locke et al., 1991); strategic and well-communicated (Conger, 1989); long-term and focused (Jacobs and Jaques, 1990; Kouzes and Posner, 1987); and inspirational, widely accepted, and integrated with visions of others (Sashkin, 1988; Sims and Lorenzi, 1992). Common views include that an effective vision should be clear, because the degree of clarity or precision in the vision statement influences how well it is understood and accepted (Jacobs and Jaques, 1990; Locke et al., 1991; Nanus, 1992; Sashkin, 1988; Sims and Larenzi, 1992); inspiring and challenging to energize employees around a value system; and clear so that the visions can be communicated 
effectively (Locke et al., 1991; Sashkin, 1988; Sims and Lorenzi, 1992). Nanus (1992) suggested that effective visions should be understood and should direct effort.

From the different characteristics proposed for visions, commonalities can be identified. They are brevity (Avery, 2004; Baum et al., 1998; Kantabutra and Avery, 2002; Locke et al., 1991); clarity (Avery, 2004; Baum et al., 1998; Jacobs and Jaques, 1990; Kantabutra and Avery, 2002; Locke et al., 1991; Nanus, 1992; Sashkin, 1988; Sims and Larenzi, 1992; Williams-Brinkley, 1999); future orientation (Avery, 2004; Baum et al., 1998; Jacobs and Jaques, 1990; Kantabutra and Avery, 2002; Kotter, 1997; Lipton, 1996; Locke et al., 1991; Senge, 1990; WilliamsBrinkley, 1999); stability (Avery, 2004; Baum et al., 1998; Kantabutra and Avery, 2002; Locke et al., 1991); challenge (Avery, 2004; Baum et al., 1998; Kantabutra and Avery, 2002; Locke et al., 1991; Nanus, 1992; Sashkin, 1988; Sims and Lorenzi, 1992); abstractness (Avery, 2004; Baum et al., 1998; Locke et al., 1991); and desirability or ability to inspire (Avery, 2004; Baum et al., 1998; Kantabutra and Avery, 2002; Locke et al., 1991; Sashkin, 1988; Sims and Lorenzi, 1992; Williams-Brinkley, 1999).

In his attempt to develop a vision theory, Kantabutra (2009a) asserts that the seven vision attributes interactively create a significant impact on overall organizational performance through emotionally committed followers. A brief vision alone will not significantly impact overall performance because it may not be clear to followers as to what needs to be done, or it may not challenge followers to do their best. A clear vision alone will not significantly impact follower satisfaction because it may be too long, making it difficult for a leader to communicate it frequently. It also may not be abstract, thus making it difficult to form a group to carry out the vision. Moreover, abstractness reflects stability in the vision because it implies no drastic change over time. An unstable vision suggests to the followers a lack of managerial integrity and commitment to the vision, negatively affecting follower satisfaction. A brief, clear, abstract, challenging, and stable vision will not draw follower commitment in working toward the vision unless it is inspiring or desirable. In addition, when a vision is not inspiring or desirable, it is difficult to develop a shared vision, hypothesized to be critical to organizational performance. An inspiring vision that is only clear, brief, abstract, challenging, and stable will have no power to attract commitment from the followers because it does not offer a view of a better future. Without a better future picture, followers cannot be drawn from where they presently are to work toward the vision. Therefore, combining all seven vision attributes is expected to influence a vision's effectiveness. Empirically, Kantabutra's Vision theory has gained support (e.g. Kantabutra, 2008; Kantabutra and Avery, 2007; Kantabutra, 2006).

As for vision content, defined as 'imagery', there is no common agreement in the literature, possibly because many leaders have difficulty explaining how they arrived at their vision (Nanus, 1992). This is understandable, given that the strategic content of a vision may focus on products, services, markets, organizations or even ideals (Westley and Mintzberg, 1989). However, a successful strategic vision appears to take into account industry, customers, and an organization's specific competitive environment in identifying an innovative competitive position in the industry (Pearson, 1989), ideally differentiating the content across visionary organizations (Collins and Porras, 1994). For example, in the entrepreneurship context, growth is a key content focus (e.g. Bird, 1992; Carriere, 1989; Gartner, Bird, and Starr, 1992), because an entrepreneur's leading role is to create jobs and expand their markets (Kuratko and Welsch, 1994; Timmons, Smollen and Dingee, 1990).

For the purpose of developing a general model, school efficiency imagery is proposed as the core element of public school vision content, because school efficiency has been extensively cited as an important school performance indicator (e.g. Bessent, Bessent, Kennington and Reagan, 1982; Bradley, Johnes and Millington, 2001; Charnes, Cooper and Rhodes, 1981; Kantabutra, 2009b), particularly for public schools. Therefore, it is hypothesized that the more school leaders imagine about enhancing efficiency in their visions, the better the efficiency outcomes for two reasons: (a) venture growth imagery was found to make an impact on venture growth (Baum et al., 1998); and (b) customer and staff satisfaction imageries were significantly correlated with customer and staff satisfaction in Australian retailers (Kantabutra, 2003).

In this model, leaders are defined as school principals. Followers are defined as teachers. Therefore, a shared vision is a vision shared between a school principal and his/her teachers. 


\section{PUBLIC SCHOOL PERFORMANCE OUTCOMES}

Generally, educational organizations have multiple objectives and multiple outputs. As such, many of them cannot be unambiguously measured or quantified. Developing measures of school performance is thus essential for performance-based school reform (Bifulco and Bretschneider, 2001), although it is notoriously difficult to do so (Monk, 1990).

Given that public schools are a major expenditure component for taxpayers in each country, the resulting efficiency is an important public policy issue (Mante and O'Brien, 2002). School efficiency is thus commonly agreed as a critical performance indicator for policy makers (Bradley et al., 2001; Mante and O'Brien, 2002), without claiming that it exhaustively explains overall school performance. In addition, a major benefit of studying school efficiency is that it provides guidelines on how inefficient schools can improve further (Soteriou, Karahanna, Papanastasiou and Diakourakis, 1998; Mante and O’Brien, 2002).

In Thailand, the education sector has received the largest share of total public expenditure for the last decade. Also, public schools have been the major educational services providers of the country. Although various schemes for improving the quality or the efficiency of public schools have been proposed, with greater efforts to raise the level of educational quality and efficiency, the desired improvements in the educational system have not been fully achieved as reported in government studies (e.g. Office of the Education Council [OEC], 2004; Office of the National Education Commission [ONEC], 2001, 2003). Furthermore, although several studies conducted in Thailand have measured school efficiency in terms of economic efficiency (e.g. Settatam, 1992), teaching and school administration efficiency (e.g. Tangsirichaipong, 1989), little published research has measured school efficiency by taking into consideration of school inputs and outputs.

A technique recognized as an appropriate approach to measure public school efficiency in this input-output context is a non-parametric technique called Data Envelopment Analysis (DEA) (Charnes, Cooper and Rhodes, 1978). The basic idea of the DEA is to view schools as productive units using multiple inputs to generate multiple outputs. DEA has been used extensively to evaluate the performance of educational systems due to its several unique advantages over other traditional techniques, e.g. ratio analysis and regression analysis (Kantabutra, 2009b; Kantabutra and Tang, 2006; Sexton, 1986; Seiford and Thrall, 1990). The DEA approach adopts a benchmarking approach to assess efficiency of schools in relation to others in their group. Through this process, the technique offers insights into efficiency of schools as compared to their peers, and provides public schools with potential improvement targets.

Widely recognized as a useful school performance measurement, the DEA approach has been extensively cited as an important method to assess school performance (e.g. Bessent et al., 1982; Bradley et al., 2001; Charnes et al., 1981; Duncombe, Miner and Ruggiero, 1995; Kantabutra, 2009b; Kirjavainen and Loikkanen, 1998; Mancebón and Bandrés, 1999; Mante and O'Brien, 2002; McCarty and Yaisawarng, 1993; Soteriou et al., 1998). Therefore, the DEA approach is adopted as a measure of public school efficiency in the proposed model.

In measuring school efficiency, input and output variables must be considered either to evaluate whether schools have actually been minimizing their resources in the most efficient way to produce student outcomes, referred to as input-oriented approach, or to evaluate whether schools have been maximizing student outcomes in the most efficient way by using their limited resources, referred to as output-oriented approach (Coelli, Rao and Battese, 1998; Fried, Lovell and Schmidt, 1993). Inputs and outputs are defined as follows:

a) school inputs are the main resources used to enhance student knowledge. These inputs are teacher-student ratio (Bessent et al., 1982; Mancebón and Bandrés, 1999; Mante and O'Brien, 2002), educational level of teachers (Bessent et al., 1982; Kirjavainen and Loikkanen, 1998; Soteriou et al.,1998), teaching experience (Bessent et al., 1982; Kirjavainen and Loikkanen, 1998), and school size (Soteriou et al.,1998). Generally, the inputs used in the analysis are controlled by the school. However, one of the most significant and robust results of input-output studies has been that students' socioeconomic and family status (SES) affects student achievement (see e.g. Hanushek, 1986; Rutter, Maughan, Mortimore, Ouston and Smith, 1979). SES thus should also be taken into consideration as a non-school input. In the proposed model, parent 
education is adopted (Kirjavainen and Loikkanen, 1998; Mancebón and Bandrés, 1999; Soteriou et al., 1998) as a proxy for SES.

b) student outputs or outcomes consist of standardized examination or national test scores (Bessent et al., 1982; Kirjavainen and Loikkanen, 1998; Mancebón and Bandrés, 1999; Mante and O’Brien, 2002) and attendance rate (Bradley et al., 2001).

Since DEA is not a statistical approach with which the theoretically based hypotheses can be tested with classical assessments, the proposed strategy in this paper follows the study of Kirjavainen and Loikkanen (1998) which tried to construct variables that would be operational counterparts to at least some of the elements in the educational production function literature (e.g. Hanushek, 1979). Such variables describing the influences of schooling on student achievement are family background, peers, school inputs and innate abilities on student achievement. Due to the lack of a clear criterion for selecting the number of variables to be included in the DEA analysis, three different efficiency models are proposed here, proceeding from a simplest data set to more complicated ones. The input and output variables included in three different models are presented in Table 1.

Measuring school efficiency using the three efficiency models is proposed because the relationship between school efficiency and shared vision between principal and teacher visions at different dimensions needs to be explored. These dimensions are (a) the dimension of school resources as in Efficiency Model 1; (b) the dimension of school resources with student composition as in Efficiency Model 2; and (c) the dimension of school resources with student composition and their socioeconomic characteristics as in Efficiency Model 3. By having three efficiency models with different inputs and outputs, it is worth noting that as the number of variables in each model increases, the efficiency score either increase or remain the same and tend to increase average efficiency scores. Thus average efficiency scores of each different model cannot be compared with each other. Each model is discussed in greater detail next.

Table 1: Variables Used In The DEA Efficiency Models

\begin{tabular}{lccc}
\hline \multicolumn{1}{c}{ Inputs } & Model 1 & Model 2 & Model 3 \\
Teacher-student ratio & & $\mathrm{X}$ & $\mathrm{X}$ \\
Educational level of teachers & $\mathrm{X}$ & $\mathrm{X}$ & $\mathrm{X}$ \\
Teaching experience & $\mathrm{X}$ & $\mathrm{X}$ & $\mathrm{X}$ \\
School size (no. of students) & & $\mathrm{X}$ & $\mathrm{X}$ \\
Parents' education & & & \\
$\quad$ Outputs & & & \\
National test score & & $\mathrm{X}$ \\
$\quad$ Verbal ability & $\mathrm{X}$ & $\mathrm{X}$ \\
$\quad$ Numerical ability & $\mathrm{X}$ & $\mathrm{X}$ & $\mathrm{X}$ \\
$\quad$ Analytical ability & $\mathrm{X}$ & $\mathrm{X}$ & $\mathrm{X}$ \\
Attendance rate & & $\mathrm{X}$ & \\
\hline
\end{tabular}

In Efficiency Model 1, the utilization of school resources is measured directly into the student outcomes. The input variables are measured by the educational level of teachers, teaching experience and teacher-student ratio. For the outcomes, the comprehensive national achievement test, or the Thai Scholastic Aptitude Test (SAT), is required to be taken by all twelfth grade students at the secondary school level since 2001. The SAT is a test that measures verbal, numerical and analytical abilities students, which have the maximum scores of 35,35 and 30 , respectively. The SAT is the educational tool used to test the developed ability of students from their learning experience.

Efficiency Models 2 and 3 take into consideration aspects of students as inputs, because schools cannot produce any output without students. Students thus are viewed as a necessary school resource as well. Therefore, Efficiency Model 2 includes two aspects of students as input: number of students, and output: attendance rate. Since public schools in Thailand cannot choose how many students to educate, the number of students and attendance rate are adopted to investigate their impact on school efficiency in the proposed model. 
In Efficiency Model 3, the role of student socioeconomic and family status (SES) is included by incorporating educational level of their parents as an additional non-discretionary input from Efficiency Model 2 since SES is consistently found to affect student performance.

Following the studies of Mante and O'Brien (2002), an output orientation DEA model is used to measure school efficiency in the present proposal. Each efficiency model is interpreted as follow. A school with an efficiency score of one is characterized as efficient relative to other schools under observation. Vice versa, efficiency scores more than one is characterized as inefficient in relation to others.

From the review of the empirical and theoretical literature above, significant, positive relationships between vision attributes (of brevity, clarity, stability, abstractness, future orientation, challenge, desirability or ability to inspire) and content (relating to school efficiency imagery) shared between school principal and teachers, and efficiency outcomes, as measured by the three models, are anticipated.

\section{PROPOSED RESEARCH MODEL}

Although relationships between shared vision and public school performance are not yet well understood, Figure 1 illustrates a model proposing a positive relationship between shared vision between principal and teachers, and public school efficiency outcomes as measured by the three efficiency models, derived from the literature review.

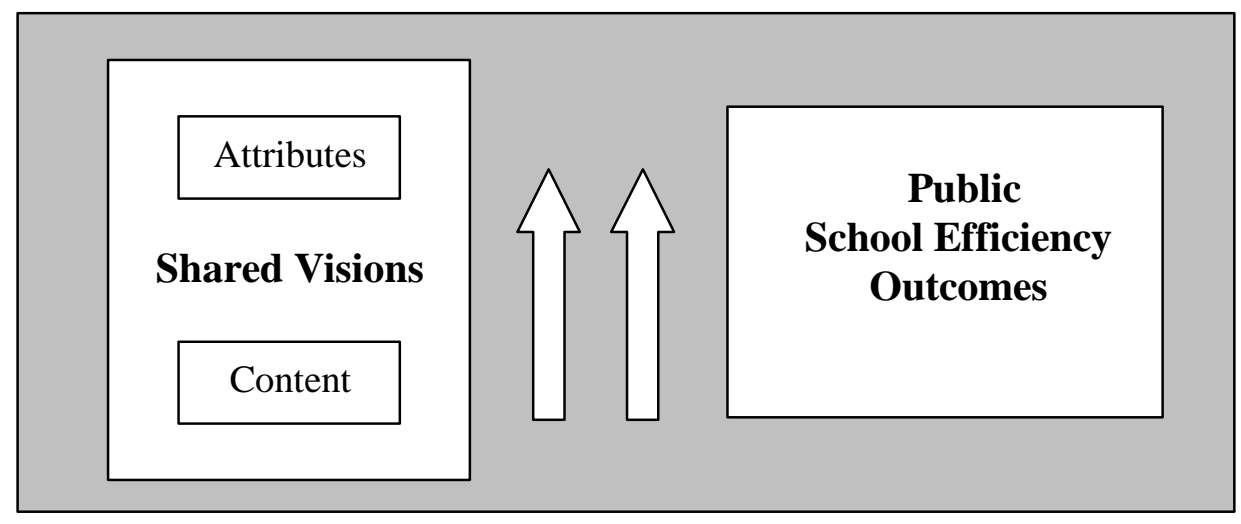

Figure 1: Measurement Model Relating Shared Vision Components To Efficiency Outcomes

Given the criticality of shared vision between leader and followers, it is anticipated that positive relationships exist between shared vision, measured by the similarity in vision attributes and content of school principal and teacher visions, and efficiency values derived from the three efficiency models. Since the literature continues pointing out positive effects of vision on performance, directional hypotheses are adopted. Based on the proposed model, the following hypotheses are advanced.

Hypothesis 1: There is a positive correlation between similarity in vision attributes and content between principal and teacher visions, and school efficiency as measured by the school inputs of educational level of teachers, teaching experience, and teacher-student ratio to the school outputs of national test scores of verbal, numerical, and analytical abilities.

Hypothesis 2: There is a positive correlation between similarity in vision attributes and content between principal and teacher visions, and school efficiency as measured by the school inputs of educational level of teachers, teaching experience, teacher-student ratio, and number of students to the school outputs of national test score and attendance rate. 
Hypothesis 3: There is a positive correlation between similarity in vision attributes and content between principal and teacher visions, and school efficiency as measured by the school inputs of educational level of teachers, teaching experience, teacher-student ratio, number of students, and the non-school input of parent education, to the school outputs of national test score and attendance rate.

Although research points out that school leaders can influence school effectiveness through a shared vision, school leaders in Southeast Asia have not been aware of the essence of a shared vision for school and how they can foster it. Endorsing this view, numerous scholars point out that developing nations in the Asia Pacific region need to develop their own knowledge base on school leadership, because their existing knowledge base is less mature than in the industrialized West (e.g. Bajunid, 1996; Cheng, 1995; Hallinger, 1995, 2003; Kantabutra, 2005). For example, when Thai school leaders receive formal leadership training, they generally learn Western-derived frameworks that usually lack even the mildest forms of cultural validation (Cheng, 1995; Swierczek, 1988). This lack of cultural validation indicates the need to test the proposed model in Thailand. Therefore, future research is needed to test the three hypotheses to provide a starting point for other researchers in the region, who might later on want to incorporate vision realization factors (Kantabutra, 2005) in their future studies. One critical area is to test whether shared visions are correlated with higher school efficiency than other visions. It would be interesting to examine the extent to which shared visions between school principal and teachers create such an effect on public school performance. Findings from future studies will improve our understanding of transformational leadership in Thai public schools.

\section{AUTHOR INFORMATION}

Sooksan Kantabutra, Leadership Research Group, College of Management, Mahidol University, Bangkok 10400, Thailand. E-mail: cmsooksan@ mahidol.ac.th

\section{REFERENCES}

1. Avery, G. C. (2005), Leadership for Sustainable Futures: Achieving Success in a Competitive World, Edward Elgar, Cheltenham, UK.

2. Avery, G.C. (2004), Understanding Leadership, Sage, London.

3. Avery, G.C. and Bergsteiner, H. (2010), Honeybees \& Locusts: The Business Case for Sustainable Leadership, Allen \& Unwin, Sydney.

4. Baetz, M. C. and Bart, C. K. (1996), "Developing mission statements which work", Long Range Planning, Vol. 29, pp. 526-533.

5. Bajunid, I. A. (1996), "Preliminary explorations of indigenous perspectives of educational management: the evolving Malaysian experience", Journal of Educational Administration, Vol. 34 No.5, pp. 50-73.

6. $\quad$ Bass, B. M. (1985), Leadership And Performance Beyond Expectations, Free Press, New York.

7. Baum, I. R., Locke, E. A. and Kirkpatrick, S. A. (1998), “A longitudinal study of the relation of vision and vision communication to venture growth in entrepreneurial firms", Journal of Applied Psychology, Vol. 83, pp. 43-54.

8. Bennis, W. G. and Nanus, B. (1985), Leaders: The Strategies For Taking Charge, Harper and Row, New York.

9. Bessent, A., Bessent, E., Kennington, E. and Reagan, B. (1982), “An application of mathematical programming to assess the productivity in the Houston independent school district”, Management Science, Vol. 28, pp. 1355-1367.

10. Bifulco, R. and Bretschneider, S. (2001), "Estimating school efficiency: a comparison of methods using simulated data", Economics of Education Review, Vol. 20 No.5, pp. 417-429.

11. Bird, B. (1992), "The operation of intentions in time: the emergence of the new venture", Entrepreneurship Theory and Practice, Vol. 17, pp. 11-20.

12. Bolman, L. and Deal, T. (1992), "Leading and managing: effects of context, culture, and gender", Educational Administration Quarterly, Vol. 22, pp. 314-329.

13. Bradley, S., Johnes, G. and Millington, J. (2001), "The effect of competition on the efficiency of secondary schools in England”, European Journal of Operational Research, Vol. 135 No.3, pp. 545-568. 
14. Caldwell, B. (1998), "Strategic leadership, resource management and effective school reform", Journal of Educational Administration, Vol. 36 No.5, pp. 445-461.

15. Carriere, J. B. (1989), Strategic vision: An empirical study, paper presented at the fourth annual conference of the International Council for Small Business, Windsor, Ontario, Canada.

16. Charnes, A., Cooper, W. W. and Rhodes, E. (1978), "Measuring the efficiency of decision making units", European Journal of Operational Research, Vol. 2, pp. 429-444.

17. Charnes, A., Cooper, W. W. and Rhodes, E. (1981), "Evaluation program and managerial efficiency: an application of data envelopment analysis to program follow through", Management Science, Vol. 27, pp. $668-697$.

18. Cheng, K. M. (1995), "The neglected dimension: cultural comparison in educational administration”, in Wong, K.C. and Cheng, K.M. (Eds.), Educational Leadership And Change: An International Perspective, Hong Kong University Press, Hong Kong, pp .87-104.

19. Cheng, Y. C. and Townsend, T. (2000), "Educational change and development in the Asia Pacific region: Trends and issues", in Townsend, T. and Cheng, Y.C. (Eds.), Educational Change And Development in the Asia Pacific: Challenges For The Future, Swets and Zeitlinger, Lisse, Netherlands, pp. 318-343.

20. Coelli, T., Rao, D. S. P. and Battese, G. E. (1998), An Introduction To Efficiency And Productivity Analysis, Kluwer, Boston.

21. Collins, J. C. and Lazier, W. C. (1992), Beyond Entrepreneurship, Prentice Hall, Englewood Cliffs, NJ.

22. Collins, J. C. and Porras J. I. (1994), Built To Last: Successful Habits Of Visionary Companies, London, Century.

23. Conger, J. A. (1989), The Charismatic Leader: Beyond The Mystique Of Exceptional Leadership, JosseyBass, San Francisco.

24. Deal, T. and Peterson, K. (1990), The Principal's Role In Shaping School Culture, US Government Printing Office, Washington D.C..

25. Deal, T. E. and Kennedy, A. A. (1982), Corporate Cultures, Penguin, London.

26. Den Hartog, D. N., House, R., Hanges, P. and Ruiz-Quintanilla, S. (1999), "Culture specific and crossculturally generalizable implicit leadership theories: are attributes of charismatic/transformational leadership universally endorsed?”, Leadership Quarterly, Vol. 10 No.2, pp. 219-256.

27. Dimmock, C. and Walker, A. (1998), "Transforming Hong Kong's schools: trends and emerging issues", Journal of Educational Administration, Vol. 36 No.5, pp. 476-491.

28. Doz, Y. L. and Prahalad, C. K. (1987), "A process model of strategic redirection in large complex firms: the case of multinational corporations", in Pettigrew, A. (Eds.), The Management Of Strategic Change, Basil Blackwell, Oxford, England, pp. 63 - 83.

29. Drath, W. H. (2001), The Deep Blue Sea: Rethinking The Source Of Leadership, Jossey-Bass, San Francisco.

30. Duncombe, W. D., Miner, J. and Ruggiero, J. (1995), "Potential cost savings from school district consolidation: a case study of New York", Economics of Education Review, Vol. 14 No. 3, pp. 265-284.

31. Fried, H. O, Lovell, C. A. K. and Schmidt, S. (1993), The Measurement Of Productive Efficiency: Techniques And Applications, Oxford University Press, NY.

32. Fullan, M. (1990), The New Meaning Of Educational Change, Teachers College Press, NY.

33. Gartner, W. B., Bird, B. J. and Starr, J. (1992), "Acting as if: differentiating entrepreneurial from organizational behavior", Entrepreneurship Theory and Practice, Vol. 16, pp. 13-30.

34. Hallinger, P. (1995), "Culture and leadership: Developing an international perspective in educational administration”, UCEA Review, Vol. 36 No.1, pp. 3-7.

35. Hallinger, P. (1998), "Educational change in Southeast Asia: the challenge of creating learning systems", Journal of Educational Administration, Vol. 36 No.5, pp. 492-509.

36. Hallinger, P. (2003), "School leadership preparation and development in global perspective", in Hallinger, P. (Ed.), Reshaping The Landscape Of School Leadership Development: A Global Perspective, Swets and Zeitlinger, Lisse, Netherlands, pp. 274-289).

37. Hallinger, P. and Heck, R. (1996), "Reassessing the principal's role in school effectiveness: a review of empirical research 1980-1995", Educational Administration Quarterly, Vol. 32 No.1, pp. 5-44.

38. Hallinger, P. and Heck, R. (1997), "Exploring the principal's contribution to school effectiveness", School Effectiveness and School Improvement, Vol. 8 No.4, pp. 1-35. 
39. Hallinger, P. and Heck, R. (2002), "What do you call people with visions? the role of vision, mission and goals in school leadership and improvement”, in Leithwood, K., Hallinger, P. and Colleagues (Eds.), The Handbook Of Educational Leadership And Administration (2 ${ }^{\text {nd }}$ ed.), Kulwer, Dordrecht, pp. 9-40.

40. Hanushek, E. A. (1979), "Conceptual and empirical issues in the estimation of education production functions", Journal of Human Resources, Vol. 14, pp. 351-388.

41. Hanushek, E. A. (1986), "The economics of schooling: production and efficiency in public schools", Journal of Economics Literature, Vol. 26, pp. 1141-1177.

42. Hargreaves, A. and Fullan, M. (1998), What Is Worth Fighting For Out There?, Teachers College Press, NY.

43. Hopkins, D. and Ainscow, M. (1993), Making Sense Of School Improvement: An Interim Account Of The IQEA Project, Paper presented at the ESRC Seminar Series on School Effectiveness and School Improvement, Sheffeld.

44. Hours: Secondary Schools And Their Effects On Children, Open Books, London.

45. Hunt, J. G. (1991), Leadership: A New Synthesis, Sage, Newbury Park, CA.

46. Intasan, J. (2002), A Study Of Academic Affairs Administration Of Pilot Schools In The Foundation Curriculum Implementation Project B.E. 2544 Of The Office Of The National Primary Education Commission, Master's thesis, Faculty of Education, Chulalongkorn University, Bangkok.

47. Jacobs, T. O. and Jaques, E. (1990), "Military executive leadership", in Clark, K.E. and Clark, M.B. (Eds.), Measures Of Leadership, Leadership Library of America, West Orange, NJ, pp. 281-295.

48. Kantabutra, S. \& Avery, G.C. (2010). The power of vision: Statements that resonate. Journal of Business Strategy, 31(1), 37-45.

49. Kantabutra, S. (2003), An Empirical Examination Of Relationship Between Vision Components, And Customer And Staff Satisfaction In Retail Apparel Stores In Sydney, Australia, Doctoral dissertation, Macquarie Graduate School of Management, Sydney.

50. Kantabutra, S. (2005), "Improving public school performance through vision-based leadership", Asia Pacific Education Review, Vol. 6 No. 2, pp. 124-136.

51. Kantabutra, S. (2006), "Leader and follower factors in customer and employee satisfaction: it takes two to tango", Journal of Applied Business Research, Vol. 22 No.4, pp. 33-45.

52. Kantabutra, S. (2008), "Vision effects in Thai retail stores: practical implications", International Journal of Retail and Distribution Management, Vol.36 No.4, pp. 323-342.

53. Kantabutra, S. (2009a), "Toward a behavioral theory of vision in organizational settings", Leadership and Organization Development Journal, Vol. 30 No. 4, pp. 319-337.

54. Kantabutra, S. (2009b), "Using a DEA management tool through a nonparametric approach; An examination of urban-rural effects on Thai school efficiency", International Journal of Education Policy \& Leadership, Vol. 4 No. 2, pp. 1-14.

55. Kantabutra, S. (2010), "Vision effects: A critical gap in educational leadership research", International Journal of Educational Management, Vol.24 No.5, pp.376-390.

56. Kantabutra, S. (2010a), "What do we know about vision?" in Hickman G.R. (Ed), Leading Organizations: Perspectives for a New Era, Sage, Thousand Oaks, CA.

57. Kantabutra, S. and Avery, G. C. (2002), "Proposed model for investigating relationships between vision components and business unit performance”, Journal of Management and Organization, Vol. 8 No. 2, pp. 22-39.

58. Kantabutra, S. and Avery, G. C. (2005), "Essence of shared vision: empirical investigation", New Zealand Journal of Human Resources Management, Vol. 5, pp. 1-28.

59. Kantabutra, S. and Avery, G.C. (2007), "Vision effects in customer and staff satisfaction: An empirical investigation", Leadership and Organization Development Journal, Vol.28 No.3, pp. 209-229.

60. Kantabutra, S. and Tang, J.C.S. (2006), "Urban-rural and size effects on school efficiency: the case of northern Thailand", Leadership and Policy in Schools, Vol. 5 No. 4, pp. 35-377.

61. Kirjavainen, T. and Loikkanen, H.A. (1998), "Efficiency differences of Finnish senior secondary schools: an application of DEA and Tobit analysis", Economics of Education Review, Vol. 17 No.4, pp. 377-394.

62. Kotter, J. P. (1997), "Leading by vision and strategy”, Executive Excellence, Vol. 14 No. 10, pp. 15-16.

63. Kotter, J. P. (1990), A Force For Change: How Leadership Differs From Management, Free Press, New York.

64. Kotter, J. P. (1996), Leading Change, Harvard Business School Press, Boston, MA. 
65. Kouzes, J. M. and Posner, B. Z. (1987), The Leadership Challenge: How To Get Extraordinary Thing Done In Organizations, Jossey-Bass, San Francisco.

66. Kuratko, D. F. and Welsch, W. P. (1994), Entrepreneurial Strategy: Text And Cases, Dryden Press, Fort Worth, TX.

67. Leithwood, K. (1994), "Leadership for school restructuring”, Educational Administration Quarterly, Vol. 30 No.4, pp. 498-518.

68. Lipton, M. (1996), "Demystifying the development of an organizational vision", Sloan Management Review, Vol. 37 No.4, pp. 83-91.

69. Locke, E. A., Kirkpatrick, S., Wheeler, J. K., Schneider, J., Niles, K., Goldstein, H., Welsh and Chah, D.O. (1991), The Essence Of Leadership, Lexington Books, New York.

70. Manasse, A. L. (1986), "Vision and leadership: paying attention to intention", Peabody Journal of Education, Vol. 63 No.1, pp. 150-173.

71. Mancebón, M. J. and Bandrés E. (1999), "Efficiency evaluation in secondary schools: the key role of model specification and of ex post analysis of results", Education Economics, Vol. 7 No. 2, pp. 131-152.

72. Mante, B. and O'Brien, G. (2002), "Efficiency measurement of Australian public sector organizations: the case of state secondary schools in Victoria", Journal of Educational Administration, Vol. 40 No.3, pp. 274296.

73. McCarty, T. and Yaisawarng, S. (1993), "Technical efficiency in New Jersey school districts", in Fried, H., Lovell, K. and S. Schmidt (Eds.), The Measurement Of Productive Efficiency, Oxford University Press, Oxford, pp. 271-287.

74. Monk, D. (1990), Educational Finance: An Economic Approach, McGraw-Hill, New York.

75. Murphy, J. and Adams, J. (1998), "Reforming America's schools 1980-2000", Journal of Educational Administration, Vol. 36 No.5, pp. 426-444.

76. Nanus, B. (1992), Visionary Leadership: Creating A Compelling Sense Of Direction For Your Organization, Jossey-Bass, San Francisco.

77. Office of the Education Council. (2004), Education In Thailand 2004, Amarin Printing and Publishing, Bangkok.

78. Office of the National Education Commission. (2001), Education In Thailand 2001/2002, Kurusapa Ladprao Publishing, Bangkok.

79. Office of the National Education Commission. (2003), Education In Thailand 2002/2003, Amarin Printing and Publishing, Bangkok.

80. Pearson, A. E. (1989), "Six basics for general managers”, Harvard Business Review, Vol. 67 No.4, pp. 94101.

81. Peters, T. J. and Waterman, R. H. J. (1982), In Search Of Excellence, Warner Books, New York, New York.

82. Phillips, R. L. and Hunt, J. G. (1992), "Strategic leadership: an introduction", in Phillips, R.L. and Hunt, J.G. (Eds.), Strategic Leadership: A Multiorganizational-level Perspective, Quarum, Westport, CT, pp. 314.

83. Rafferty, A. E. and Griffin, M.G. (2004), "Dimensions of transformational leadership: conceptual and empirical extensions”, Leadership Quarterly, Vol. 15, pp. 329-354.

84. Reardon, K. K. (1991), Persuasion In Practice, Sage, Newbury Park, California.

85. Rutter, M., Maughan, B., Mortimore, P., Ouston, J. and Smith, A. (1979), Fifteen Thousand

86. Sashkin, M. (1985), "Creating a corporate excellence culture: identifying levers and how to use them", Emprender (Spanish; Mendoza, Argentina), Vol. 21 No.145, pp. 36-39.

87. Sashkin, M. (1988), “The visionary leader”, in Conger, J.A. and Kanungo, R. N. (Eds.), Charismatic Leadership: The Elusive Factor In Organizational Effectiveness, Jossey-Bass, San Francisco, pp. 122-160.

88. Seiford, L. M. and Thrall, R. M. (1990), "Recent developments in DEA", Journal of Econometrics, Vol. 46, pp. 7-38.

89. Sekkhunthod, K. (2002), A Study Of State And Problems Of Strategic Planning Of Pilot Schools On Performance-based Budgeting's Administrators Under The Office of the National Primary Education Commission, Master's thesis, Faculty of Education, Chulalongkorn University, Bangkok.

90. Senge, P. M. (1990), The Fifth Discipline: The Art And Practice Of The Learning Organization, Currency Doubleday, New York. 
91. Settatam, P. (1992), A Study On Economic Efficiency Of Public Secondary School In Bangkok Metropolitan Area, Master's thesis, Faculty of Education, Chulalongkorn University.

92. Sexton, T. R. (1986), "The methodology of data envelopment analysis", in Silkman, R.H. (ed.), Measuring Efficiency: An Assessment Of Data Envelopment Analysis, Jossey-Bass, San Francisco, Vol. 32, pp.7-72.

93. Sims, H. P., Jr. and Lorenzi, P. (1992), The New Leadership Paradigm: Social Learning And Cognition In Organizations, Sage, Newbury Park, CA.

94. Siriwat, W. (2002), A Study Of School Basic Curriculum Construction In Schools Under The Education Department, Muang Pattaya Authority, Master's thesis, Faculty of Education, Chulalongkorn University, Bangkok.

95. Soteriou, A. C., Karahanna, E., Papanastasiou, C. and Diakourakis, M. S. (1998), "Using DEA to evaluate the efficiency of secondary schools: the case of Cyprus", International Journal of Educational Management, Vol. 12 No.2, pp. 65-73.

96. Stoll, L. and Fink, D. (1992), "Effecting school change: the Halton approach", School Effectiveness and School Improvement, Vol. 3 No.10, pp.19-41.

97. Stoll, L. and Fink, D. (1994), "School effectiveness and school improvement: voices from the field", School Effectiveness and School Improvement, Vol. 5 No.2, pp. 149-177.

98. Swierczek, F. (1988), "Culture and training: how do they play away from home?", Training and Development Journal, Vol. 42 No.11, pp. 74-80.

99. Tangsirichaipong, R. (1989), A Comparison Of Educational Resources, Teaching Efficiency And School Administration Efficiency Among Secondary Schools In Thailand Classified By Sizes, Types, And Locations, Master's thesis, Faculty of Education, Chulalongkorn University.

100. Teddlie, C. and Reynolds, D. (2000), The International Handbook Of School Effectiveness Research, Falmer Press, London.

101. Theppudthangkul, W. (2001), A Study Of The Educational Quality Assurance Planning Process Of Secondary Schools Under The Department of General Education in Bangkok Metropolis, Master's thesis, Faculty of Education, Chulalongkorn University.

102. Timmons, J. A., Smollen, L. E. and Dingee, A. L. M., Jr. (1990), New Venture Creation: Entrepreneurship In The 1990s., Richard D. Irwin, Homewood, IL.

103. Westley, F. and Mintzberg, H. (1989), "Visionary leadership and strategic management", Strategic Management Journal, Vol. 10, pp. 17-32.

104. Williams-Brinkley, R. (1999), "Excellence in patient care demands a clear vision in action", Health Care Strategic Management, Vol. 17 No.1, pp. 18-19. 